\title{
IMAGENS POBRES E A OSTENTAÇÃO DO PIXEL - RELAÇÕES ENTRE CINEMA E INTERNET EM VIDEOFILIA (E OUTRAS SÍNDROMES VIRAIS)
}

\author{
Regiane AKemI ISHII* \\ Universidad de São Paulo \\ regiane.ishii@gmail.com
}

Recibido: 15/5/2020 Aceptado: 20/8/2020

DOI: https://doi.org/10.26439/contratexto2020.n034.4867

Resumo. Este artigo é dedicado à análise fílmica de Videofilia (e outras síndromes virais) (2015), de Juan Daniel F. Molero, e sua relação narrativa e estética com a internet, destacando a presença de glitches e datamoshing, técnicas que ampliam a visibilidade dos píxeis. Relacionaremos tal uso com o conceito de imagens pobres, termo cunhado por Hito Steyerl em que a autora apresenta a ambivalência das imagens que perdem resolução para ganhar velocidade e difusão. Também serão mobilizadas reflexões recentes da teoria do cinema por meio de autores como D.N. Rodowick, Francesco Casetti e Thomas Elsaesser. Assim, será possível investigar alguns modos pelos quais o cinema tem confrontado, atuado e respondido ao status das imagens contemporâneas, em que produção e circulação se tornam indistinguíveis.

Palavras-chave: cinema contemporâneo / cinema e internet / Hito Steyerl

\section{IMÁGENES POBRESY LA OSTENTACIÓN DEL PIXEL - RELACIONES ENTRE CINE E INTERNET EN VIDEOFILIA (Y OTROS SÍNDROMES VIRALES)}

Resumen. Este artículo está dedicado al análisis cinematográfico de Videofilia (y otros síndromes virales) (2015), de Juan Daniel F. Molero, y su relación narrativa y estética con la internet, destacando la presencia de glitches y datamoshing, técnicas que incrementan la visibilidad de los píxeles. Relacionaremos ese uso con el concepto de imágenes pobres, término acuñado por Hito Steyerl, en el que la autora presenta la

\footnotetext{
* Doctoranda en el Programa de Posgrado en Medios y Procesos Audiovisuales de la Universidad de São Paulo, Brasil (véase: http://orcid.org/0000-0001-5448-2111).
} 
ambivalencia de las imágenes que pierden resolución para ganar velocidad y difusión. Se sumarán asimismo discusiones recientes alrededor de la teoría cinematográfica a partir de autores como D.N. Rodowick, Francesco Casetti y Thomas Elsaesser. Así, será posible investigar algunas de las formas con las cuales el cine ha enfrentado, actuado y respondido al estatus de las imágenes contemporáneas, en el que la producción y la circulación se vuelven indistinguibles.

Palabras clave: cine contemporáneo / cine e internet / Hito Steyerl

\title{
POOR IMAGES AND THE OSTENTATION OF THE PIXEL: RELATIONS BETWEEN CINEMA AND THE INTERNET IN VIDEOPHILIA (AND OTHER VIRAL SYNDROMES)
}

\begin{abstract}
This article aims at conducting a film analysis of Videophilia (and Other Viral Syndromes) (2015), by Juan Daniel F. Molero, and its narrative and esthetic relationship with the Internet, highlighting the presence of glitches and datamoshing, techniques that increase the visibility of pixels. We will relate such use with the concept of poor images, a term coined by Hito Steyerl, in which the author presents the ambivalence of images that lose resolution to gain speed and diffusion. Recent reflections on film theory will also be mobilized through authors such as D. N. Rodowick, Francesco Casetti and Thomas Elsaesser. Thus, it will be possible to examine some of the ways with which cinema has confronted, acted on and responded to the status of contemporary images, where production and circulation become indistinguishable.
\end{abstract}

Keywords: contemporary cinema / cinema and Internet / Hito Steyerl 
Quanto mais eu acordo durante a noite, melhor. Porque meus sonhos mudam, e se enredam e se transformam. Talvez por isso eu goste da internet. É tão estranho quanto.

De Videofilia <E outras síndromes virais>.
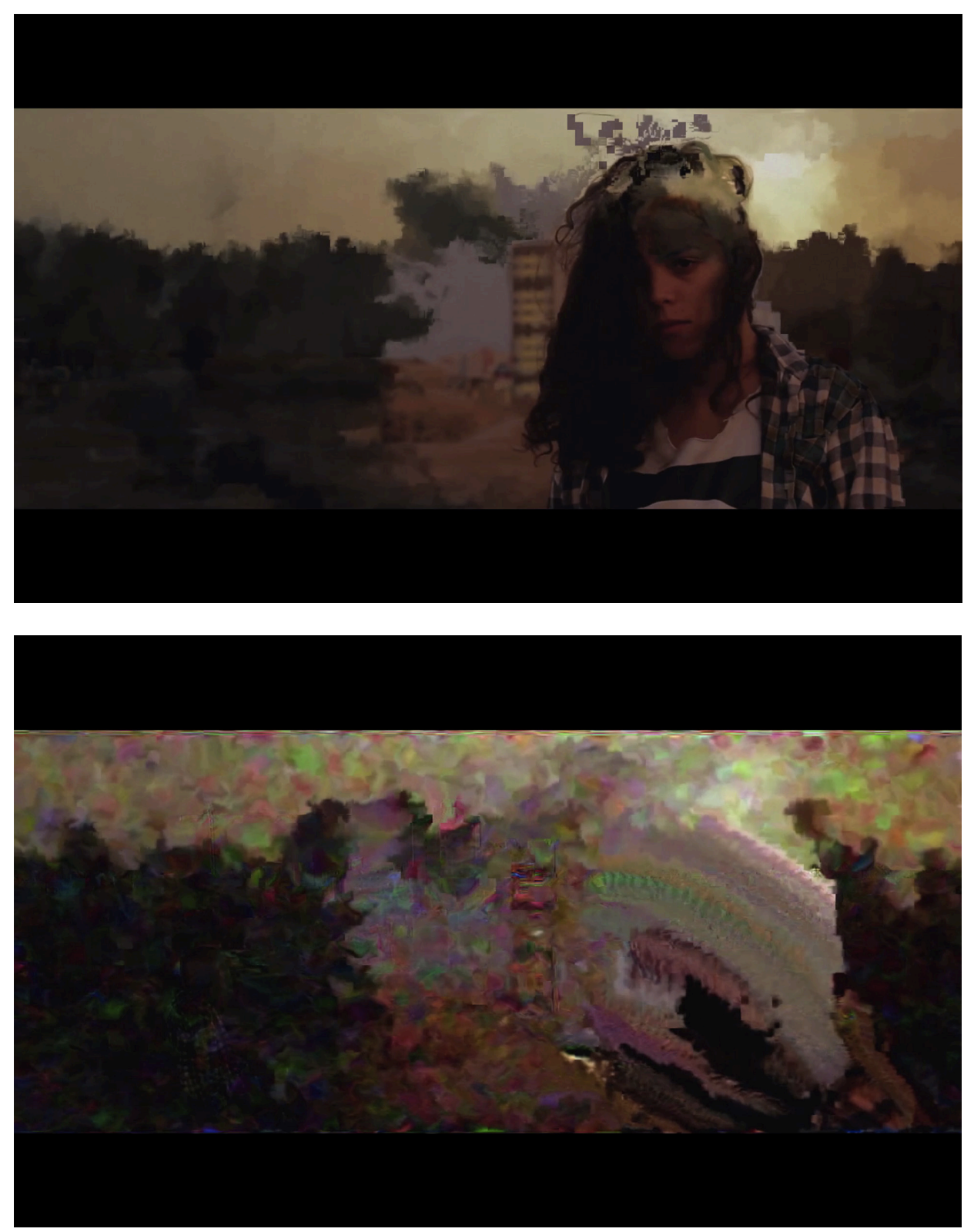

Figuras 1 e 2. Still de Videofilia <E outras síndromes virais> 


\section{INTRODUÇÃO}

Imagens feridas, corroídas, propositadamente degradadas. Em Videofilia (e outras síndromes virais) [Videofilia (y otros síndromes virales)] (2015), de Juan Daniel F. Molero, os jovens Luz (Muki Sabogal) e Junior (Ter Om) se conhecem na internet e passam a se seduzir por meio de mensagens e videochamadas masturbatórias no Facebook. Quando se encontram nas ruas de Lima, capital peruana, aliam seus desejos sexuais à produção de vídeos caseiros que têm como destino plataformas on-line e lojas de DVDs pornôs. As imagens de seus vídeos em baixa resolução, com seus píxeis aparentes, estão em constante transformação, assim como as imagens de seus games e de suas alucinações com ácidos e álcool. Quanto mais tensos os acontecimentos da narrativa, mais extremos são os tratamentos dados às imagens. Assumindo sua precariedade, as imagens de Videofilia parecem tão vulneráveis e suscetíveis à manipulação quanto um spam ou as stories do Instagram.

Videofilia, assim como é possível observar em outros títulos recentes, assume explicitamente o vínculo com a internet: forma e conteúdo estão relacionados à navegação on-line, afetando toda a construção espaço-temporal fílmica. 0 modo com que tal produção responde e se alia à web, ou cria embates e se insurge contra a internet, a torna específica e, acreditamos, potente para a reflexão audiovisual contemporânea. É mobilizado um novo vocabulário para a análise fílmica, ao mesmo tempo em que são retomados pontos que sempre foram caros à teoria do cinema.

Para a artista e pesquisadora Hito Steyerl, cujo pensamento é estruturante para nossa reflexão, a produção se misturou com a circulação a ponto de se tornarem indistinguíveis. À medida que a web se espalha por uma dimensão diferente, a produção de imagens se desloca para muito além dos limites dos campos especializados (Steyerl, 2017, p. 149). Nossa hipótese é de que a condição identificada pela autora, em que a produção e a circulação de imagens estão intrinsicamente relacionadas, tensiona questões centrais à criação cinematográfica, gerando uma "retroalimentação" entre as mídias.

Partindo desse pensamento, este artigo é dedicado à análise fílmica de Videofilia e sua intensa relação com o universo on-line, destacando o que denominamos uma ode à estética do erro. Há uma ostentação do pixel, por meio do uso de glitches e datamoshing, instigando questionamentos e experimentações que dizem respeito tanto ao cinema quanto à internet.

Observamos a presença das imagens pobres ${ }^{1}$, termo cunhado também por Steyerl, em que a autora apresenta a ambivalência de imagens que perdem resolução para

1 "In defense of the poor images" é o título original do ensaio de Steyerl, publicado pela primeira vez na plataforma e-flux em 2009. Disponível em http://www.e-flux.com/journal/10/61362/ in-defense-of-the-poor-image/. Acesso em 15.10.2017. Posteriormente, o ensaio integrou o livro The wretched of the screen (2012). No artigo, utilizamos citações traduzidas para o português no ensaio "Em defesa da imagem ruim", publicado na revista Serrote (2015). Optamos, porém, por utilizar ao longo do texto a expressão imagens pobres e não ruins. 
ganhar velocidade e difusão, transformando qualidade em acessibilidade. Trata-se de thumbnails, spams ${ }^{2}$, arquivos que tiveram seu nome deliberadamente trocado e foram jogados na rede sem genealogia identificável. Uma imagem "comprimida, reproduzida, ripada, remixada, e também copiada e colada em outros canais de distribuição" (Steyerl, 2015, p. 185) e que agora integra (ou invade) o cinema.

Jonathan Crary, após dedicar-se em diversos títulos à questão da visão, percepção e atenção no século 19 e à formação da cultura visual moderna, também refletiu sobre o estado atual de demanda por visibilidade e conexão permanentes. Em 24/7 - Capitalismo tardio e os fins do sono (2014):

É claro que ninguém pode fazer compras, jogar games, trabalhar, escrever em seu blog, fazer downloads ou enviar mensagens de texto $24 / 7$. No entanto, uma vez que não existe momento, lugar ou situação no qual não podemos fazer compras, consumir ou explorar recursos em rede, o não tempo de $24 / 7$ se insinua incessantemente em todos os aspectos da vida social e pessoal. Já não existem, por exemplo, circunstâncias que não podem ser gravadas ou arquivadas na forma de imagens ou informações digitais. (Crary, 2014, p. 40)

Esse estado de circulação das imagens é relativamente novo: a data oficial do nascimento da internet é $1989^{3}$. Frequente em diferentes graus no cotidiano do usuário da internet, tal vocabulário abarca algumas das ferramentas e operações empreendidas na intensa produção, edição e recepção de imagens nos dias de hoje.

Nossa experiência vem sendo redefinida por inúmeros elementos como os exemplificados que, longe do alcance de uma coesão unificadora, caracterizam a manutenção de um estado de transição contínuo e um campo de batalha em que as presenças on-line e off-line estão cada vez mais mescladas e colididas. Se os filmes sempre estiveram atentos a esse cenário, poderíamos identificar que os modos de fazer cinema influenciados, instigados e confrontados pela navegação na internet e a profusão de imagens em um regime $24 / 7$ estão cada vez mais presentes.

2 A autora possui um instigante ensaio voltado especificamente para a questão do spam: “The Spam of the Earth: Withdrawal from Representation" (Steyerl, 2012, p. 160).

3 Por conta do marco das três décadas da web, o ano de 2019 contou com análises e linhas do tempo dos pontos marcantes de sua história, frequentemente comparando o cenário inicial de sua criação com o contexto atual, muito mais monetizado e vigiado. Há diversos projetos que apresentam uma nostalgia de uma internet mais livre, traço que também nos interessa por sua presença em certa produção fílmica. Essa questão é explorada em “The early internet is breaking - here's how the World Wide Web from the 90s on will be saved". Disponível em https://www.youtube.com/ watch?v=2LzyRcLJdlg. Acesso em 11.01.2020. 
Aqui ${ }^{4}$, situamos nosso interesse em filmes que, assim como Videofilia, ganharam destaque em festivais de cinema, curadorias de $\operatorname{mostras}^{5}$ e relevância da crítica. Tal escolha nos é cara para que a investigação dialogue com produções que "querem ser cinema", ou seja, que levam em consideração tanto um diálogo com a história do cinema quanto com as novas influências das mídias digitais. Assim, acreditamos que Videofilia aborde a internet menos como tema a ser representado, e mais realize a experimentação de contornos audiovisuais de um estar no mundo com a internet.

Contextualizando a carreira do título no circuito cinematográfico, vale dizer que a produção já estava sendo filmada quando recebeu o apoio do Hubert Bals [fundo econômico do Festival de Roterdã para projetos em curso], em 2014. No mesmo festival, no ano seguinte, recebeu o prêmio principal Tiger Hivos ${ }^{6}$. No material de divulgação do festival sobre o filme destacam-se o encontro entre o imaginário on-line, povoado de píxeis e glitches, e o contexto peruano, com suas ruínas, mitos e mídia sensacionalista.

Além do Festival de Roterdã, o filme teve uma carreira em eventos como o Festival de Mar del Plata, Queer Lisboa, T-Mobile New Horizons International Film Festival (Breslávia, Polônia) e exibições em instituições como o MoMA (Nova York) e La casa encendida (Madrid). A fortuna crítica, ainda que com várias observações negativas, em geral destacou sua experimentação formal considerando seus esforços para embaralhar "o real e o virtual", gerando um terreno pantanoso que embaça a divisão entre fora e dentro ou público e privado.

Em seu país de origem, o título foi eleito o melhor filme de 2016 pela Associação Peruana de Imprensa Cinematográfica, além de ter ganhado o prêmio de distribuição do Ministério da Cultura e, curiosamente, ter sido selecionado como representante para concorrer ao Oscar de filme estrangeiro. A crítica local aponta Videofilia como um ponto de inflexão na produção peruana mais recente, marcada pela trajetória iniciada por $A$ teta assustada (La teta asustada, 2009), de cunho realista. Em direção contrária, Videofilia

4 Este artigo é parte da pesquisa de doutorado Conexão cinema-internet: a circulação online em filmes contemporâneos, em desenvolvimento na Universidade de São Paulo (Brasil), sob orientação da Profa. Dra. Cecília Antakly de Mello.

5 Entre as iniciativas recentes, podemos citar as mostras "Born digital - Raised by the internet" (2019), no British Film Institute (Londres, Reino Unido), "erro_404 - 30 anos da web" (2019), no Cinusp (São Paulo, Brasil), e "O desktop é um palco", na conferência Besides the screen 2019 Inteligências gráficas e ficções algorítmicas (Vitória, Brasil).

60 prêmio foi dividido com La obra del siglo, de Carlos M. Quintela, e Vanishing Point, de Jakrawal Nilthamrong. 0 júri foi formado por Rolf de Heer, Maja Miloš, José María Prado Garcia, Ichiyama Shozo e Johanna ter Steege. 0 anúncio oficial declarou: "Videofilia (e outras síndromes virais), de Juan Daniel F. Molero, explora a relação entre o mundo jovem e o mundo em rápida mudança com uma verdade inabalável. Sua anarquia e seu toque visual refletem seu tema. 0 filme mergulha profundamente em águas perturbadoras e necessárias." Tradução nossa. Disponível em: http:// press.iffr.com/110273-iffr-2015-awards-announced. Acesso em 06.04.2020. Em 2010, o diretor apresentou o documentário Reminiscencias no mesmo festival. 
aportaria uma abordagem "maximalista", que remeteria a traços barrocos da cultura andina. No meio acadêmico, vale citar que, em 2017, o filme foi exibido na sessão de encerramento do festival de cinema da Latin American Studies Association (LASA) ${ }^{7}$, realizado na Pontificia Universidad Católica del Perú, e contou com a presença do diretor e do pesquisador Sebástian Pimentel. Em sua crítica, o também professor Pimentel trata de um "subdesenvolvimento" marcado não apenas nos espaços latino-americanos, mas também pelo pixel. "A impureza também é digital", escreveu.

Retomamos a carreira do filme justamente para salientar sua ambição "por ser cinema" e localizar a diversidade de seu circuito. Ao mesmo tempo em que é legitimado em um relevante festival, aporta outros meios de exibição, como a tela pequena dos computadores, tendo sido disponibilizado na íntegra no YouTube por alguns meses pelo próprio diretor: "Ver esses elementos serem apropriados pelo cinema e se tornarem parte de tudo aquilo que consideramos cinematográfico. Vê-lo em uma tela pequena talvez faça o oposto: ver como o cinema é apropriado pela linguagem do computador"'.

A partir dessa organização de alguns sintomas da relação entre cinema e internet, elencaremos questões que ligariam, ao mesmo tempo, pontos fundamentais para o pensamento sobre o cinema, assim como novas peculiaridades que, a todo momento, emergem desse relativo encontro recente. Em seguida, percorreremos algumas considerações da teoria do cinema presentes na literatura recente que contribuirão para a análise fílmica de Videofilia.

\section{MARCOS TEÓRICOS: O TRAÇO METALINGUÍSTICO E O DESEJO DE “SE MANTER CINEMA"}

Não à toa, o traço metalinguístico é recorrente em Videofilia. Há, declaradamente, um interesse sobre sua própria realização em meio às novas condições do meio digital conectado. Decorre um campo de tensões autorreflexivo com o qual o cinema se depara e que é perturbado pelas transformações das condições do fluxo audiovisual nos dias de hoje. Entrelaçando as narrativas e as escolhas estéticas de certa produção contemporânea, também nos parece importante identificar como o cinema tem pensado sobre

7 Agradecemos à pesquisadora Natalia Christofoletti Barrenha, da equipe organizadora e de curadoria do festival LASA, por ter sido a primeira a indicar Videofilia à nossa investigação e por nos apresentar ao diretor Juan Daniel F. Molero, que gentilmente nos cedeu o arquivo para assistirmos ao filme e realizar esta análise.

8 Em "Videofilia: nuestra crítica de la película peruana". Disponível em https://elcomercio.pe/ luces/cine/videofilia-nuestra-critica-pelicula-peruana-249670-noticia/. Acesso em 06.04.2020. Tradução nossa.

9 “Entrevista con el director de «Videofilia», Juan Daniel F. Molero: la vida real también es virtual". Disponível em https://www.cinencuentro.com/2015/06/22/pelicula-peruana-videofilia-entrevista -juan-daniel-f-molero/. Acesso em 25.02.2020. Tradução nossa. 
si mesmo neste momento em que a internet se faz tão onipresente. Se o caráter autorreflexivo sempre foi presente para o cinema, vale nos atentarmos ao que é específico deste momento e como se dão seus efeitos concretos.

Há momentos de adesão e deslumbramento, em que os artifícios são exibidos com fascínio, como se a criação quisesse se provar em sintonia com as últimas atualizações e recursos digitais. Também estão presentes as iniciativas de resistência, em que a internet, majoritariamente monetizada e controlada, é vista com desconfiança. Nesses casos, é comum que o cinema queira demonstrar que está ciente e pode se sobrepor às armadilhas da configuração online. Algumas produções querem mergulhar no caos, subverter a data mining, provar que ainda há força em certa atitude underground. Tentam romper com a navegação algoritmada e capitalizada, subvertendo o fluxo automatizado dos aplicativos de sempre..$^{10}$

As relações entre o cinema e outras mídias sempre existiram. 0 florescimento da cultura moderna no fim do século 19 e seus pontos de contato com o cinema têm sido revisitados e explorados por diversos campos de estudo. A coletânea 0 cinema e a invenção da vida moderna (2010) apontou como a cultura moderna já era "cinematográfica" antes do cinema, articulando novas formas de espetáculo, distração e mobilidade e diminuindo a distinção entre a realidade e suas representações, ponto cada vez mais explorado pelos estudos recentes. No "Prefácio à edição brasileira" da citada coletânea, Ismail Xavier afirma que

A nova história retoma essas questões e tematiza as tensões entre o narrativo-dramático e as "atrações", evitando decretar a superioridade de um sobre o outro, apenas analisando sua interação ao longo do tempo, incluída a experiência de hoje com seus efeitos especiais e a nova manipulação possibilitada pela imagem digital. Não surpreende que estejam em pauta as comparações entre momentos separados por um século. (Xavier, 2010, p. 14)

Considerando, portanto, que o cinema foi, simultaneamente, produto e parte componente das variáveis da modernidade, e não apenas um meio, reconhecemos os esforços de debruçar-se sobre a última virada de século e sua ampla transformação social, política e cultural. Como proposto pelos organizadores Leo Charney e Vanessa R. Schwartz, também gostaríamos de "começar a partir do cinema e a retornar a ele como um denominador comum unindo os séculos 19, 20 e 21 (potencialmente), a um só tempo um repositório estranho e familiar de tempos passados e um oráculo presciente do porvir" (Charney \& Schwartz, 2010, p. 27). Na mesma direção, em "Pós-cinemas: uma atualização sem começo e sem fim", José Cláudio S. Castanheira e Erick Felinto

10 Nos EUA, $96 \%$ do tempo no celular é gasto, em média, com dez aplicativos. No Brasil, $80 \%$ se dedicam a apenas dois apps. Dados disponíveis em "Vida conectada e vigiada". Disponível em https://www. nexojornal.com.br/especial/2019/12/17/Vida-conectada-e-vigiada. Acesso em 11.01.2020. 
afirmam que "o 'pós' do cinema, muitas vezes remete a um 'pré' sobre o qual ainda se especula" (Castanheira \& Felinto, 2019, p. 13). 0 primeiro cinema teria nos ensinado a buscar rupturas sem encarar a história do cinema como um conjunto de obras-primas encadeadas de geração a geração. A análise retrospectiva desse período demanda uma revisão constante, com redescobertas a todo momento. Apesar de não ser o caso de nos dedicarmos ao primeiro cinema, a ideia de que não se trata de uma história evolutiva também nos é cara.

Tendo o cinema como esse denominador comum de mobilizações fundamentais nos últimos séculos, há modos com que certa produção cinematográfica contemporânea articula uma linguagem construída ao longo de muitas décadas, ao mesmo tempo em que posiciona-se em relação ao intenso fluxo caracterizado pelas visibilidade e conexão permanentes já identificadas, atuando no rearranjo da disposição deste campo de forças. Para André Gaudreault e Philippe Marion, em 0 fim do cinema? Uma mídia em crise na era digital (2016):

O cinema não é mesmo o campo por excelência da imagem móvel? Não é mesmo, de certa forma, o modelo das hipermídias e da cultura midiática contemporânea? 0 que não impede que sua identidade seja abalada, por causa, especialmente, de inovações tecnológicas que afetam as modalidades culturais que regem seus usos. (p. 24)

Autores como Thomas Elsaesser (2015; 2018), D.N. Rodowick (2007), Francesco Casetti (2015) e os já mencionados Gaudreault e Marion (2016) dedicaram-se a analisar como o cinema tem procurado "se manter cinema", ao mesmo tempo em que negocia e se apropria de novidades. Em comum, os autores acreditam em sua capacidade de adaptação e potencial estético, que persiste ao longo de toda a história. Assim, períodos de intensa transformação tecnológica seriam instigantes para a produção artística e a teoria do cinema. Como diz Rodowick, em The virtual life of film (2007), a atividade artística não consiste em descobrir a essência de um meio, mas sim em explorar e talvez renovar ou mesmo reinventar seus poderes de expressão (p. 45). No livro, seguido por Elegy for theory (2014), o autor explora as consequências filosóficas do desaparecimento da ontologia fotográfica e do futuro da teoria do cinema.

Para ele, mais do que uma afronta à sua hegemonia, a grande profusão de telas conectadas que nos cerca poderia ser um reconhecimento da contínua relevância do cinema, ao mesmo tempo que o redimensiona como apenas uma entre várias manifestações do digital: Nossa cultura audiovisual permanece "cinematográfica" no sentido de que as formas mais populares de mídia digital desejam recriar e intensificar os efeitos cinematográficos de enquadramento, edição, ponto de vista dinâmico e enquadramento móvel. Alternativamente, como convém a um meio cujas entradas e saídas são descontínuas, a transcodificação é uma via de mão única; a perpetuação dos algoritmos 
cinematográficos na estrutura profunda da programação digital significa o desaparecimento do filme, e o renascimento do cinema na forma de algoritmos programáveis. A ideia de cinema persiste como uma forma de modelar formas espaciais baseadas no tempo com computadores, mas o cinema é apenas uma das inúmeras funções que os computadores podem simular ou modelar. Entender cinema digital, então, significa definir e avaliar os automatismos que os computadores possibilitam. Podem ser automatismos que criam efeitos semelhantes a filmes, mas não são mais automatismos cinematográficos. Nossa cultura audiovisual é atualmente uma cultura digital, mas com uma aparência cinematográfica. E o cinema, também, é cada vez mais apenas mais outro elemento da cultura digital (Rodowick, 2007, p. 133, grifo nosso).

Tal pensamento nos é relevante pois discute a "retroalimentação" das mídias. Com a popularização das câmeras de celulares e a imediata publicação das fotografias e vídeos nas redes sociais, operações como obturar, superexpor, aplicar filtros, deletar, escanear e até efetuar um close-up ou fazer um travelling, tornam-se também procedimentos mentais habituais. Nossas narrativas vitais ganham contornos audiovisuais, ou seja, gestos e episódios triviais respondem a um desejo de assemelhar-se a cenas de filmes, videoclipes e publicidades. 0 sucesso dos dispositivos conhecidos como smartphones seria uma consequência de sua capacidade de dar vazão às ambições que articulam as subjetividades contemporâneas. Esta observação é importante pois não coloca os celulares como a causa da junção entre visibilidade e conexão, mas sim os localiza dentro de um contexto de demandas que já vem sendo construído há séculos e onde o cinema desempenha papel fundamental.

Já Francesco Casetti, mais recentemente, em The Lumière Galaxy - Seven key words for the cinema to come (2015), se debruça sobre o cinema levando em conta a diversidade de dispositivos audiovisuais e a profusão de telas (celular, tablets, videoinstalações e até os monitores de aviões). Para ele, a tensão entre persistência e transformação parece estar atingindo seu ponto alto (Casetti, 2015, p. 4). Ao ser confrontado com as mudanças, por vezes o cinema se arriscaria a transformar sua própria natureza e, em outros casos, tentaria resistir e permanecer como tal. Porém, para o autor, o cinema mais frequentemente entrelaçaria essas mudanças com uma tradição e um conjunto de hábitos, incorporando-as. 0 que se destacaria é o surgimento de um campo de possibilidades e oportunidades sem precedentes, mesmo que aparentemente discordantes e em situações limítrofes. No moderado cenário apresentado por Casetti, a permanência do cinema por várias rotas nasceria de sua natureza transformadora, simultâneo ao tributo do seu legado.

Thomas Elsaesser também acredita que a transfiguração do cinema na era das redes digitais pode construir a ponte entre o cinema fílmico e pós-fílmico, sem negar as diferenças, mas reafirmando a persistência da experiência cinematográfica. Nesse 
sentido, é proposta uma teoria do cinema baseada no corpo e nos sentidos, sem um modelo linear evolucionário nem um formato de árvore genealógica. Projetos teóricos aparentemente contraditórios poderiam se complementar de modo surpreendente e inesperado, possibilitando uma nova compreensão das lógicas anteriores.

Observando a importância crescente das imagens em movimento pós-fotográficas no século 21, Elsaesser e Malte Hagener, em Film theory - An introduction through the senses, defendem que o cinema parece pronto para deixar para trás sua função de 'mídia' (para a representação da realidade), a fim de se tornar uma 'forma de vida' (e, portanto, uma realidade por si só) (2015, p. 12). Assim, o cinema não proporia apenas um modo de conhecer o mundo, mas também uma nova maneira de estar no mundo. Aqui, nossa abordagem propõe um adendo, explorando também a ideia de estar no mundo com a internet, como levantamos anteriormente. Da maneira proposta pelos autores, algumas propriedades anteriormente atribuídas à conceptualização de "janela e moldura", por exemplo, seriam revistas com a função de "portal", uma abertura que dá acesso a um "além" e novos múltiplos, como nas páginas web. Em vez de estarem a serviço de uma composição claramente circunscrita ou uma delimitação espacial e fisicamente plausível, as imagens em movimento seriam a própria face da realidade (e não mais uma porção do "mundo real").

Do mesmo modo que Rodowick, na citação mais acima, Elsaesser e Hagener consideram que o cinema é, daqui em diante, um adjetivo ou atributo do digital, e não o contrário (2015, p. 198). Ainda assim, para os autores, a mudança da fotografia para as imagens digitais não seria uma ruptura tão radical se considerarmos que os parâmetros e critérios de pertinência não são exclusivamente baseados em propriedades tecnológicas.

Já em Cinema como arqueologia das mídias (2018), Elsaesser considera que o cinema, ao longo de sua história, tem "interagido, sido dependente, sido complementado e se percebido em competição com todas as formas de entretenimento, de buscas científicas, de aplicações práticas e de usos militares". (Elsaesser, 2018, p. 20). 0 autor defende que tanto o passado quanto o futuro do cinema integram outras práticas midiáticas. Sendo assim, a ideia de arqueologia das mídias pressupõe um surgimento descontínuo, heterogêneo e interligado das mídias digitais, ao contrário de uma história linear ou de uma lógica estrita de causa e efeito. Para a arqueologia das mídias, o cinema também seria referência central.

Tal estudo vem sido reconhecido como essencial para a compreensão dos meios de comunicação contemporâneos por diversos autores (incluindo os já citados Casetti, Gaudreault, Marion e Rodowick). Ao responder "por que a arqueologia das mídias (agora)?", Elsaesser esclarece que tratou essa área de pesquisa mais como um sintoma do que como um método e que as três configurações que levaram à sua função de sintoma seriam: 1) a redescoberta do primeiro cinema; 2) as mídias digitais e 3) a imagem em 
movimento em museus e galerias. Especificamente sobre o segundo ponto, nossa zona de interesse, ele diz que as mídias digitais "nos confrontam com diversos pontos de ruptura e descontinuidades, os quais requerem uma correção de perspectiva historiográfica" (Elsaesser, 2018, p. 268). É dizer, as genealogias isoladas continham muitos pontos cegos que têm vindo à tona com a influência das mídias digitais nas diversas áreas da arte e da vida diária (entretenimento, educação, comunicação, transações comerciais, etc.).

Assim o autor mapeia o contexto atual:

As características principais desses períodos de rápida mudança midiática envolvem a volatilidade, a imprevisibilidade e até a natureza contraditória da dinâmica entre as implicações práticas das novas tecnologias (suas aplicações industriais e seu potencial econômico), sua percepção pela imaginação popular (sob a forma de narrativas de ansiedade, utopia, pânico e fantasia) e as respostas ambíguas (adoção entusiástica ou resistência firme) de artistas, escritores e intelectuais. Essas configurações mutáveis entre distintos agentes ofereceram um rico campo de investigação para análise cultural, propondo desafios metodológicos e requerendo estudos de caso específicos. (Elsaesser, 2018, p. 47)

No momento atual, o cinema, a televisão e as mídias digitais existem lado a lado, alimentando-se mutuamente e sendo cada vez mais interdependentes, sem dúvida, mas também sendo claramente distintas e até hierarquicamente posicionadas, em termos de prestígio cultural, função econômica e prazeres espectatoriais. A pergunta é: como podemos descrever ou analisar essas ligações mútuas e, ao mesmo tempo, sinalizar os espaços que distinguem cada mídia, sem voltar a dividi-las em histórias separadas? [grifo nosso] (Elsaesser, 2018, p. 87)

É exatamente nesse ponto que nos situamos, de reconhecimento tanto das ligações mútuas quanto das distinções entre as mídias, assumindo que suas trajetórias não se dão isoladamente. Podemos então sintetizar pontos de convergência nos pensamentos dos autores referidos que guiarão nossa análise: cinema como campo por excelência da imagem em movimento e modelo para as hipermídias, retroalimentação dos meios e capacidade de adaptação do cinema. É notável que, ao mesmo tempo em que reconhecem a existência de um discurso de crise (ou até de morte) do cinema, há uma base comum de certa confiança e curiosidade pelo porvir. 


\section{ANÁLISE DE VIDEOFILIA (E OUTRAS SÍNDROMES VIRAIS)}

Você fez uma cópia ruim. Está tudo pixelado.

De Videofilia <E outras síndromes virais>

Sim, no universo em que navegam os personagens de Videofilia há o Facebook (Figura 3). Mas ao mesmo tempo, nas abas vizinhas do navegador, há uma variada combinação de conteúdos: um texto intitulado "Vivemos em uma simulação feita por computadores? (A matemática por trás da Matrix)"11, fotos de Valeria Lukyanova, mulher considerada a "Barbie humana", um vídeo em que uma garota fantasiada da personagem japonesa Sailor Moon dança na praia ao som de cumbia, um relato em defesa da masturbação feminina, outro vídeo em que um homem com síndrome de Tourette canta "Losing my religion", da banda R.E.M. (Figura 4), uma série de thumbnails da categoria "Espía Peru" no site Pornhub...

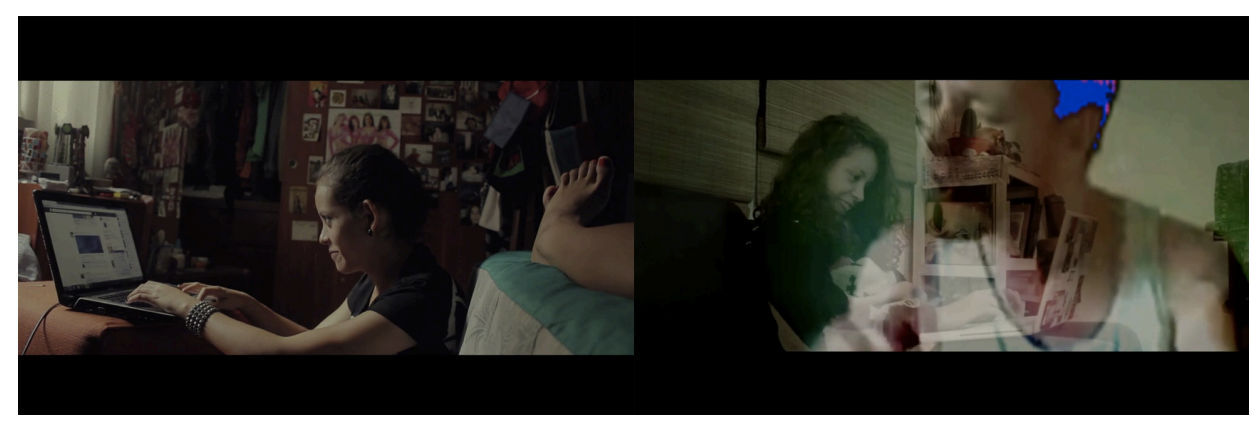

Figuras 3 e 4. Stills de Videofilia <E outras síndromes virais $>$

0 que poderia ser considerado apenas bobagens, variações de uma procrastinação qualquer ou um compilado de inutilidades é, simultaneamente, a matéria prima e a estrutura de Videofilia. Juntos, os conteúdos acessados pelos personagens e, principalmente, o modo com que se sistematiza seus ciclos de distração e enfado intermináveis são a fonte de referências para o filme. Como observado mais acima por Elsaesser, a imaginação popular que é característica desses períodos de rápida mudança midiática também pode ser percebida aqui sob a forma de narrativas de "ansiedade, utopia, distopia e fantasia". Elas se mesclam com a mesma frouxidão da navegação de um usuário corriqueiro: brevíssimos intervalos de um vídeo qualquer são intercalados com a troca de mensagens na rede social da aba ao lado. Uma propaganda salta na tela ao lado de alguma postagem de contundência duvidosa. A falha na conexão causa lentidão

11 ¿Vivimos en una simulación hecha por computadora? (las matemáticas detrás de la Matrix)”. Disponível em https://pijamasurf.com/2011/05/\%C2\%BFvivimos-en-una-simulacion-hecha-porcomputadora-las-matematicas-detras-de-la-matrix/. Acesso em 25.02.2020 
no carregamento do vídeo, que começa a travar. A tolerância pela espera é tão baixa que, após pouquíssimos segundos, a barra de rolagem de outra rede social é prontamente acionada. A procrastinação dos personagens adia algo que parece não importar para o desenvolvimento da narrativa, mas a impaciência e a apreensão típicas desse ócio on-line são as constantes que dão o tom geral do filme.

Nele, os adolescentes vivem sem distinção entre dia e noite. Habitam lan houses, sob a iluminação de monitores velhos, ou levam seus pesados notebooks para a cama. Estão sempre rodeados de fios, teclados, estabilizadores, carregadores de bateria, etc. Não apenas os arredores físicos evocam a importância do digital para o filme. Mais do que isso, como argumentamos, seus personagens estão no mundo com a internet. Nascido em 1987, o diretor, roteirista e montador Molero se identifica como integrante da primeira geração dos nativos digitais e conta que não havia encontrado muitos filmes na produção internacional que explorassem os entornos virtuais em que cresceu. "Queria que o filme fosse percebido como se tivesse sido dirigido por um dos personagens, por isso não é um estudo sobre os jovens freaks de Lima, mas uma imersão neste mundo"12, defende.

Para o projeto, o diretor conta que realizou uma investigação sobre o gênero adolescente no cinema e fincou seus interesses pela juventude da capital peruana, que não se encaixaria nos arquétipos da adolescência cinematográfica desenvolvidos por diretores estadunidenses emblemáticos das décadas de 1990 e 2000, como Gus Van Sant e Larry Clark. A romantização urbana dos skates, marca daquela produção, é substituída aqui pela navegação na deep web. Se o universo underground, com sua inclinação para comportamentos e estéticas subversivos, tem sido há décadas um terreno fértil para a produção que se dedica a filmar a experiência adolescente, em Videofilia essa postura é explorada na própria imagem em transformação e suas possibilidades de circulação on-line. Há, na intenção de Molero, certa nostalgia por uma internet mais livre e caótica, em que os algoritmos ainda não operavam com tanta eficiência visando lucros e ele fazia sites copiando, decodificando e modificando os códigos HTML, "como (...) um Frankenstein, sem importar que fosse um trabalho sujo"13. Trata-se de uma postura "faça você mesmo", em oposição aos templates, programas e aplicativos desenvolvidos por grandes corporações, que impõem tanto um padrão estético quanto uma limitação dos modos com que as ideias podem se relacionar e difundir. Nesse cenário, as "inovações" ocorrem no interior de parâmetros conceituais e funcionais restritos às decisões das plataformas.

12 “Entrevista con el director de «Videofilia», Juan Daniel F. Molero: la vida real también es virtual". Disponível em https://www.cinencuentro.com/2015/06/22/pelicula-peruana-videofilia-entrevista-juan-daniel-f-molero/. Acesso em 25.02.2020.

13 Ibid. 


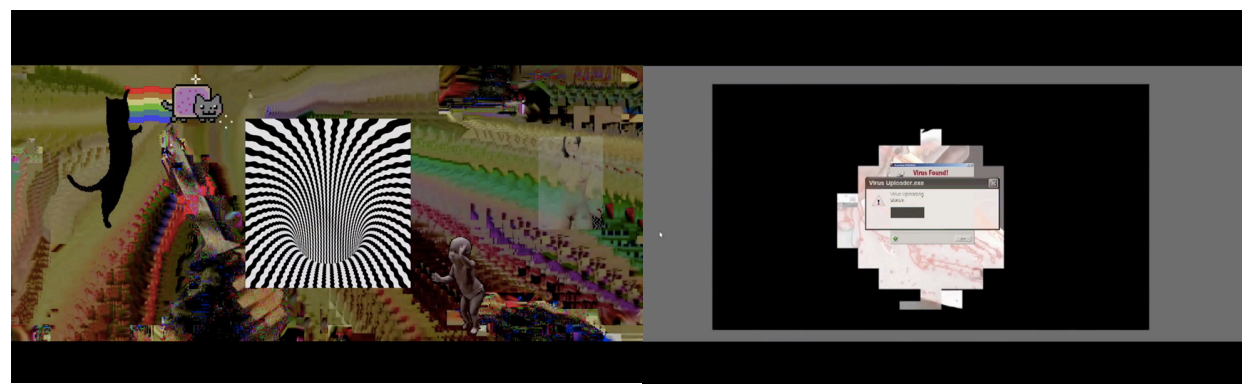

Figuras 5 e 6. Stills de Videofilia <E outras síndromes virais>

Em alguns momentos, a atmosfera gerada pelos GIFs e pop-ups (Figuras 5 e 6) que invadem as cenas ressoa o visual da internet dos anos 1990, inacabada e mais caótica. Ao contrário das plataformas Google atuais - brancas, lisas, acessíveis, supostamente neutras - ou de outros sites cujo layout parece obedecer a um mesmo padrão pré-configurado, as referências da internet anterior são os endereços hospedados via Geocities (Figura 7), em que os usuários, ainda que de maneira simplória, manejavam os códigos de seus próprios sites, tateando coletivamente a construção do que seria a www. Hoje, apesar da facilidade de realizar postagens em redes sociais, o conhecimento para propor alterações estruturais nas páginas é menos difundido.

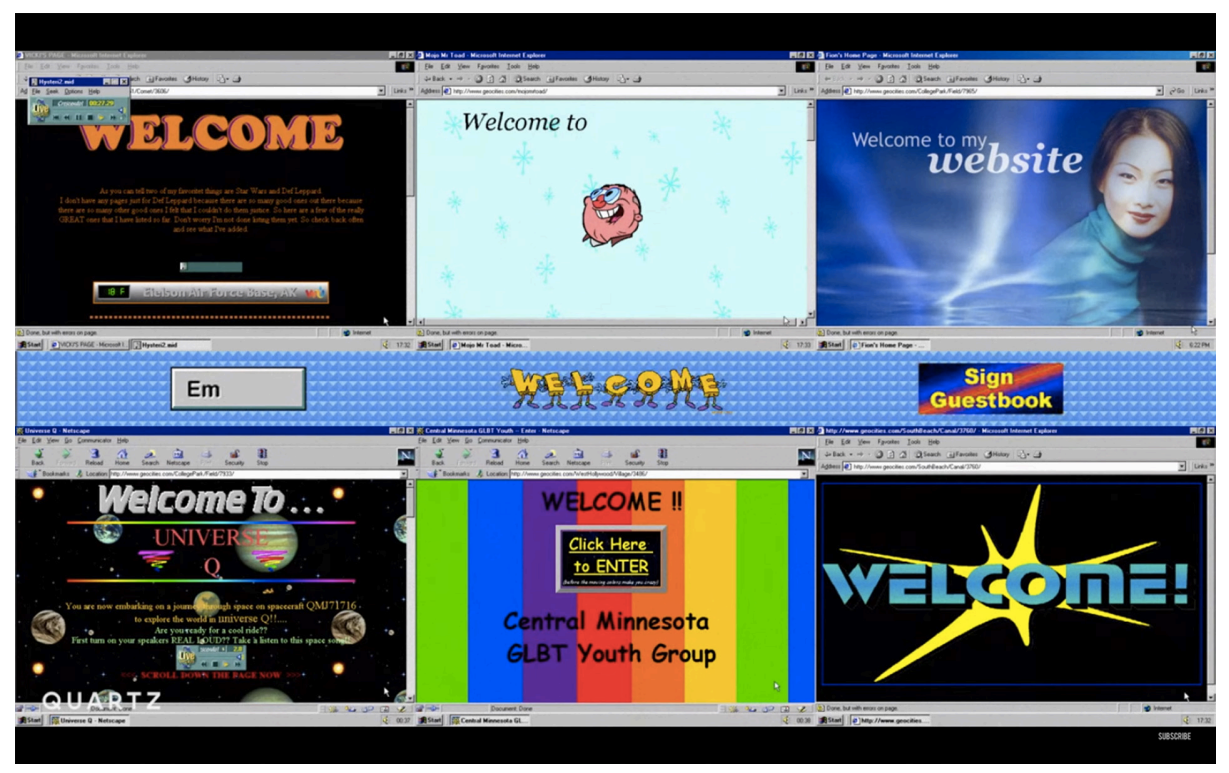

Figura 7. Still de "The early internet is breaking - here's how the World Wide Web from the 90s on will be saved" 
Outro marco importante, citado em entrevistas pelo diretor, é o 4chan, fórum de imagens criado em 2003, que tem como diferencial a dispensabilidade de cadastro, garantindo o anonimato. Dividido em boards com diretrizes e conteúdos específicos (otaku culture, retro games, do-it-yourself, random, sexy beautiful women, adult GIF, por exemplo), inicialmente dedicava-se aos mangás e animes japoneses. Desde então, os fóruns se ramificaram em uma grande diversidade de subculturas, abrigando postagens de memes bem-humorados e também de incitação à violência e misoginia ${ }^{14}$. 0 4chan é citação frequente em notícias, já que diz-se que alguns atentados e crimes de grande repercussão, envolvendo adolescentes, foram orquestrados em suas páginas ${ }^{15}$. Como é pregnante no modo como as ideias se concatenam na internet, a bobagem, o ridículo, o inocente, o perverso e o ofensivo circulam simultaneamente. Em Videofilia, o mesmo tom de "vale tudo" está presente (incluindo uma cena de homicídio gravada por celular) ou, como diz o diretor, de uma "selva virgem, onde ainda existem vários espaços desconhecidos e seres mitológicos. Onde nada está totalmente definido e prevalece um sentimento de medo, curiosidade e assombro"16.

0 prepotente protagonista Júnior, perturbado por teorias da conspiração e de fim do mundo, se anuncia como um visionário e age de modo misógino. Sua motivação por produzir algo em sintonia com as transformações de seu tempo é concentrada em esforços para realizar vídeos pornôs ${ }^{17}$. Ele acredita que as webcams transformaram a indústria pornô e defende as atrações de uma estética amadora, como registros de uma câmera que vagueia por baixo da saia de mulheres nas ruas de Lima ou do encontro com a estudante Luz em seu quarto. Nesse último, Junior usa uns óculos equipados com câmera (como um Google Glass), apostando no tom caseiro da produção e no visual colegial da garota.

Ao tentar vender seus vídeos em um quiosque de DVDs pornôs, é surpreendido pela imagem pixelada exibida na tela de uma velha televisão. Algo aconteceu na passagem das imagens do seu computador (Figura 8) para o DVD e, deste, para a televisão (Figura 9).

140 site reunia 3,329,258,976 postagens em 29.02.2020. Disponível em https://4chan.org/.

15 A versão brasileira, Dogolochan, hospedada na deep web, também é famosa pela veiculação de conteúdo criminoso, racista e misógino.

16 "Entrevista con el director de Videofilia, Juan Daniel F. Molero: la vida real también es virtual". Disponível em https://www.cinencuentro.com/2015/06/22/pelicula-peruana-videofilia-entrevista -juan-daniel-f-molero/. Acesso em 25.02.2020.

17 Vale comentar que há uma rica área de estudos acadêmicos acerca da produção audiovisual pornô e, especificamente, sobre iniciativas não-normativas que conquistaram espaço na internet (diferente da exibida em Videofilia). “Territorios obscenos y márgenes del placer: Introducción al dossier sobre pornografía, post-pornografía y audiovisual en Latinoamérica" (2018), da revista Imagofagia, reúne algumas reflexões nesse sentido. Em "Corpos, pornificações e prazeres partilhados", Mariana Baltar dedica-se ao universo netporn, destacando o portal I feel myself, dedicado às representações do prazer feminino. 
Há interesse do dono da loja pela sua produção, mas seria preciso gerar um novo arquivo. Em uma pequena cabine, eles travam uma discussão: "A realidade é como essa tela, toda pixelada e fragmentada. Você nunca vai encontrar um sentido. Apenas aproveite".
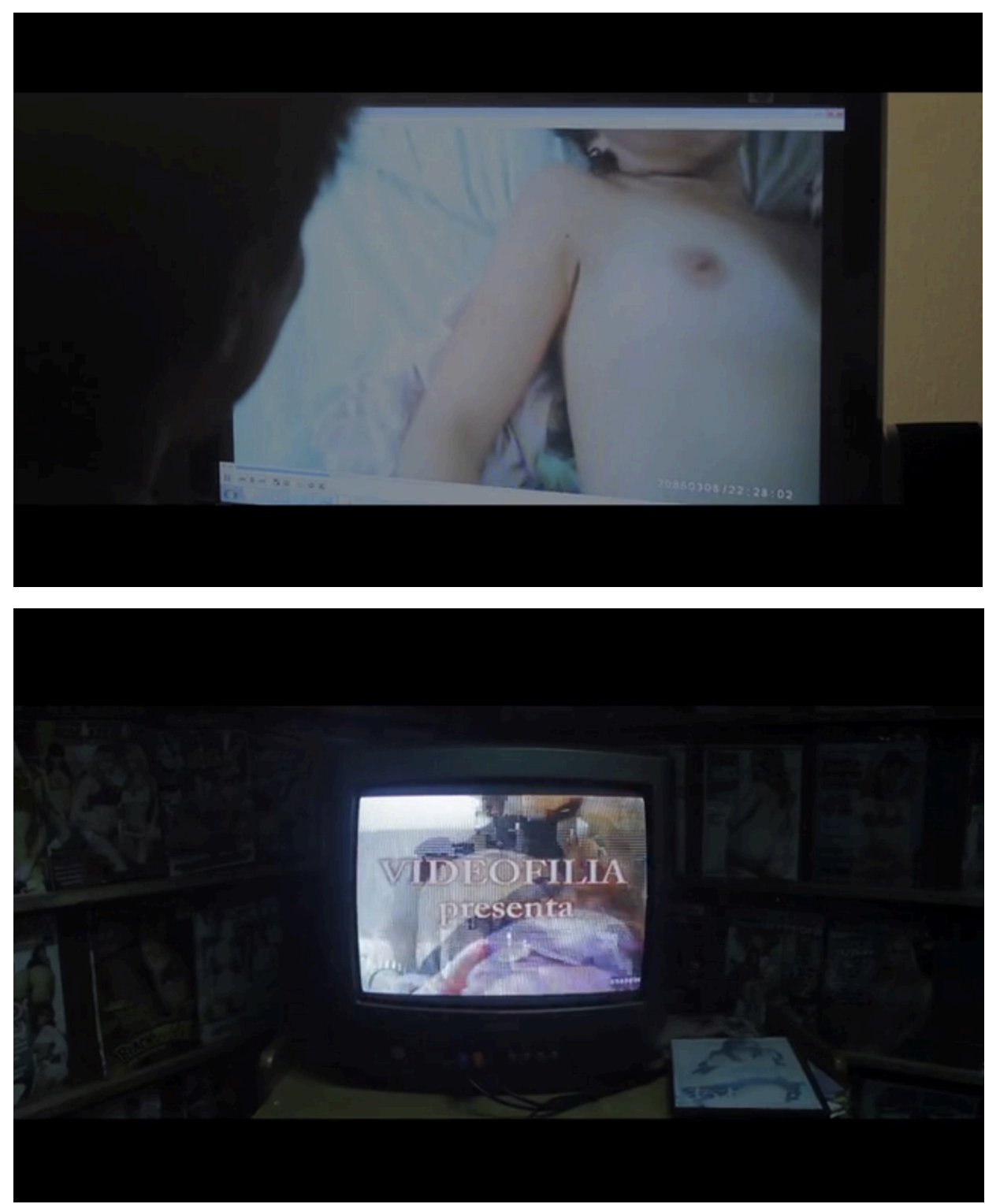

Figuras 8 e 9. Stills de Videofilia (E outras síndromes virais)

Como sinalizado em seu próprio subtítulo, síndromes virais vão interligando as rotas de Videofilia, contaminando e deteriorando mais e mais sua aparência. 0 vírus se faz 
presente pela disseminação da "pixelização" como uma ode à estética do erro. Dentro da hierarquia das imagens contemporâneas, o filme parece orgulhar-se de ser composto de imagens pobres. Para além do conteúdo, a situação dessas imagens poderia revelar as condições de marginalização e as forças sociais que as levaram a circular com baixa definição. Para Steyerl, as imagens pobres:

expressam todas as contradições da multidão contemporânea: seu oportunismo, seu narcisismo, seu desejo de autonomia e de criação, sua incapacidade de se concentrar ou se decidir, sua constante prontidão para a transgressão e a simultânea submissão. Em última análise, as imagens ruins apresentam um instantâneo da condição afetiva da multidão, sua neurose, sua paranoia, seu medo, assim como seu anseio por intensidade, diversão e distração. (Steyerl, 2015, p. 194)

0 que temos como central no pensamento de Steyerl são os nódulos e diagonais que se cruzam na produção audiovisual. Ao entrelaçar o conhecimento da história das mídias com a observação de ocorrências aparentemente ordinárias das trocas na internet, Steyerl destaca a imagem como coisa em si, e não como representação. A autora propõe mais um deslocamento, defendendo que nossa relação com as imagens não seria de identificação, mas sim de participação. Estaríamos assim diretamente imbricados nas forças e desejos que nela estão acumulados. Evocando o título de mais um de seus ensaios, as imagens seriam "uma coisa assim como eu e você" (Steyerl, 2012, p. 46), fragmentos contraditórios do mundo, nódulos que concentram questões políticas, econômicas e de entretenimento, cujas forças são cada vez mais mobilizadas por conta da internet. A ambiguidade faz parte de sua natureza, em que o experimental e o artístico estão juntos a uma grande quantidade de pornografia e paranoia, como parece ser a proposta de Videofilia.

Nesse sentido, podemos elencar algumas instâncias de produção de imagens em Videofilia, entre elas: 1) as imagens que circulam nas telas dos personagens durante suas procrastinações; 2) o vídeo pornô proposto por Júnior; 3) o vídeo pornô proposto por Luz e 4) o filme em si, por onde percorre o vírus que afeta todas essas esferas. É dizer, a produção do conjunto de imagens leva em conta seu propósito de circulação, hesitando em firmar-se com alta definição. Demonstram sua revolta e insubmissão por meio de diferentes formas de pixelização.

Telas televisivas ou monitores de computador dentro da tela de cinema, como exemplificado nas imagens acima, é um recurso já bastante habitual. No caso de Videofilia, gostaríamos de seguir com a análise da relação intrínseca entre produção e circulação, em que as telas se "contaminam" por meio das rotas que se formam entre elas. Nesse sentido, Casetti descreve que as telas dos novos dispositivos funcionariam mais como displays, lugares em que imagens flutuantes param por um momento, se tornam disponíveis para os usuários, permitem ser manipuladas e depois decolam novamente em novas rotas (Casetti, 2015, p. 12). Para ele, o próprio cinema teria se aproximado da 
lógica de um display: as imagens pareceriam mais precárias, menos limitadas à narrativa e abertas a diferentes significados. 0 display - sendo a touchscreen sua manifestação máxima - apenas viabilizaria a presença das imagens, formando um entre vários mundos possíveis. Não seria mais possível contar com uma circunscrição única.

0 mundo de Videofilia é repleto de falhas, marcadas pelo uso excessivo de glitches, datamoshing e referências à net art. Retomando a definição original da palavra glitch (um mau funcionamento ou falha repentina do equipamento, geralmente temporária $\left.{ }^{18}\right)$, chama a atenção a natureza efêmera e o efeito de revés, como uma adversidade ou fracasso. No âmbito da produção de imagens, o efeito glitch é alcançado por meio de mudanças em pequenas partes do código digital, gerando um tipo de "bagunça" na disposição dos píxeis. Ficou conhecido como uma tentativa de trazer à tona em sua aparência o sistema interno das imagens, como uma advertência de que sua estrutura é distinta do status das imagens fotográficas que estávamos habituados. Manifesta-se um descompromisso com a inteligibilidade.

Apesar de ter iniciado como um tipo de desobediência19 o glitch assumiu, há tempos, um espaço na produção mainstream. 0 indesejado - aspectos visuais que denotavam falhas, acidentes e imprevistos entre a transmissão e a recepção das imagens - tornouse estimado em diversas obras. Hoje, não é necessário saber alterar o código da imagem digital, mas apenas eleger variações do efeito em ferramentas como Snorpey, Pixel Sorter, ImageGlitcher ou o aplicativo Glitche.

A pretensão de corromper a produção audiovisual teve como um dos resultados o datamoshing, uma técnica de compressão que remove keyframes de um arquivo, fazendo com que os píxeis do vídeo se "derramem". Deletando dados das imagens estáticas identificáveis do vídeo (conhecidas como l-frames), as informações abstratas (os P-frames) preenchem os espaços entre as imagens (como pode ser visto na abertura deste artigo nas Figuras 1 e 2).

Os glitches e datamoshing se relacionam com o movimento Net Art, arte feita na e para a internet que emergiu na década de 1990 e também alcançou reconhecimento no sistema das artes visuais ${ }^{20}$ por meio de nomes como a artista russa Olia Lialina e o estadunidense Takeshi Murata. Uma das referências para Videofilia, Monster movie (2005) ${ }^{21}$,

18 Disponível em https://www.lexico.com/definition/glitch. Acesso em 29.02.2020. Tradução nossa.

19 Em 2010, 2011 e 2012 ocorreu, em Chicago (EUA), o festival GLI.TC/H que reuniu artistas, teóricos e entusiastas do glitch. A iniciativa contou com o apoio do Film, Video, New Media, and Animation department da School of the Art Institute of Chicago (SAIC).

20 A Tate reconhece o termo Net Art e os subgêneros browser art, software art e telematic art. Para mais referencias cronológicas e nomes de artistas vinculados ao movimento, ver: https://www. tate.org.uk/art/art-terms/i/internet-art. Acesso em 01.03.2020.

21 Disponível em https://vimeo.com/147761897. Acesso em 26.02.2020. 
de Murata, tido como um dos precursores do datamoshing, extrai um trecho do filme-B Caveman (1981), em que um monstro emerge de um pântano fervilhante, para decompor sua forma e as cores originais em 30 frames por segundo.

Segundo o diretor, o vírus de Videofilia "intoxicaria a linguagem cinematográfica"22(grifo nosso). Assim, seus esforços se concentraram em afastá-lo do que pareceria um "filme proiissional", de alta definição. Na pós-produção, Molero forçava a manipulação para mais píxeis aparecerem até que Omar Quezada, diretor de fotografia, começou a trabalhar com presets na câmera desde a captação. Ambos também decidiram por integrar um "pixel morto"23 (pixel "defeituoso", que permanece escuro na tela de exibição) como parte do filme.

As estratégias definidas por Molero e pelo diretor de fotografia de Videofilia, fundindo as decisões de captação e pós-produção, nos leva à outra reflexão de Steyerl. A autora situa que, tradicionalmente, pós-produção significava sincronizar, mixar, editar, corrigir cores e outros procedimentos realizados depois da filmagem. Mais recentemente, a pós-produção começou a dizer respeito à produção como um todo. A pós-produção, em um sentido muito literal, é a produção hoje. Isso também muda a temporalidade inerente ao termo pósprodução. 0 prefixo "pós-", que denota um histórico passado de um estado imóvel, é substituído. Nós não estamos após a produção. Em vez disso, estamos em um estado em que a produção é infinitamente reciclada, repetida, copiada e multiplicada, mas também potencialmente também deslocada, humilhada e renovada. $A$ produção não é apenas transformada, mas fundamentalmente deslocada para locais que costumavam formar seu exterior: para dispositivos móveis, telas dispersas, fábricas e passarelas, berçários, realidade virtual, linhas de produção offshore. Ela é infinitamente editada e recombinada. (Steyerl, 2012, p. 183)

No contexto de sua reflexão, Steyerl pressupõe o alcance da ideia de pós-produção para além do universo da arte e das mídias. Ao mesmo tempo, defende que não podemos entender a realidade sem refletir sobre o cinema, a fotografia, a modelagem 3D ou a animação. Para ela, estaríamos todos imersos em um processo infinito de pós-produção. Esse entendimento vai ao encontro da noção $24 / 7$ proposta por Crary, em que a realidade de nosso tempo se caracteriza pela manutenção de um "estado de transição contínuo" (Crary, 2014, p. 46). Como não é possível localizar o instante em que a produção cessa, tampouco haveria um momento em que alcançaríamos ou nos familiarizaríamos com qualquer ordem tecnológica específica. A instabilidade seria uma das marcas da redefinição de nossa experiência.

A noção de que a própria realidade é pós-produzida também nos interessa para a análise de Videofilia. Aqui, as ferramentas normalmente consideradas como recursos 
de pós-produção audiovisual não têm como objetivo alcançar uma "boa representação" ou apenas retocar as imagens que já foram apreendidas. Elas se tornam meios para a criação, a serviço do desenvolvimento da própria história. 0 roteiro depende da relação entre a imagem e o mundo, ou melhor, do vão e das lacunas que aparecem entre eles, e dão lugar à especulação e intensa ansiedade.

É nessa falha que se desenvolve a última parte do filme, a partir da produção proposta por Luz, com a participação de Júnior. No vídeo, de tons slasher, o sexo é acompanhado de simulação de esfaqueamento e sangue barato, fabricado pela própria adolescente. Como um subgênero do horror, o slasher se caracteriza pela perseguição e morte violenta de jovens (predominantemente mulheres). Após a realização do vídeo, ela o disponibiliza on-line, no turbilhão de produções pornôs, sob o título "minha namorada se comportou mal e the dei o merecido haha".

Em seguida, ambos se encontram em uma festa à fantasia em que os participantes usam roupas e acessórios de figuras cultuadas nos fóruns on-line, como os personagens japoneses Sailor Moon e Dragon Ball. Regada a muito álcool e drogas, o encontro vai ganhando tons de pesadelo e tormenta, com a cena cada vez mais degradada. As alucinações ganham forma com a intensificação das transformações das imagens (Figura 10). Sem explicações, Luz deixa a festa e desaparece.

A suspeita pelo seu sumiço recai sobre Junior, que entra em um delírio cada vez mais turbulento. 0 vírus segue se alastrando pelas janelas dos navegadores que continuam se abrindo, pelos devaneios dos personagens e, por fim, pelas imagens do vídeo protagonizado por Luz e Junior que vem à tona, reforçando a suspeita da responsabilidade pelo desaparecimento da garota. As denúncias ganham forma até no "mundo analógico" da primeira página de um jornal nas bancas.

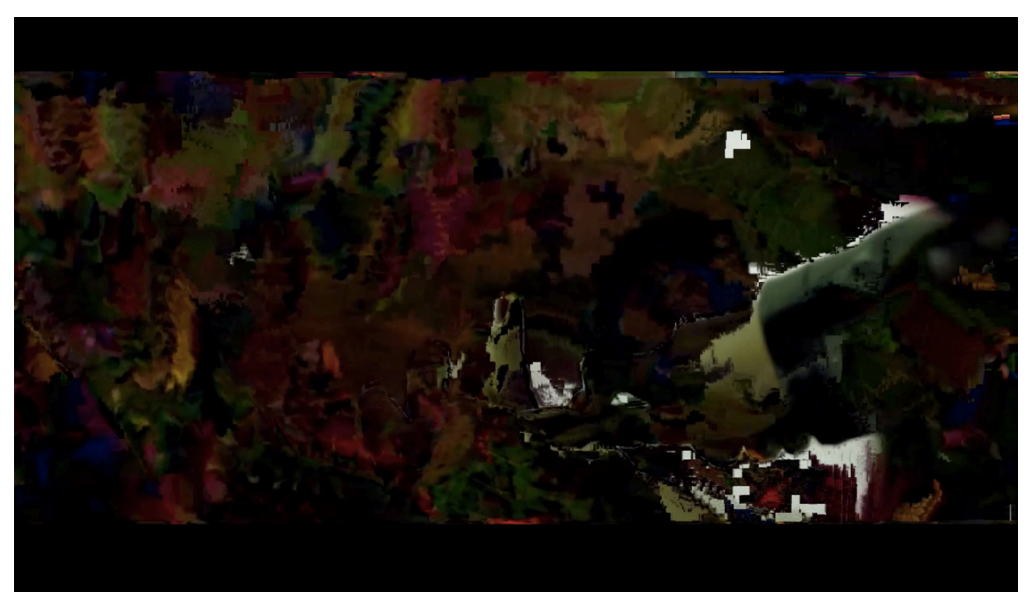

Figura 10. Still de Videofilia (E outras síndromes virais) 
Descontextualizadas, as imagens do esfaqueamento de Luz ganharam outro significado diante de seu desaparecimento. Foi como se o comando $\mathrm{Ctrl}+\mathrm{X}^{24}$ tivesse sido acionado de um acontecimento para o outro. Os píxeis do vídeo fantasioso abalaram "a vida real" ou, como se diz na linguagem da internet, IRL (in real life). As ligações URL-IRL, mais do que mescladas, são literalmente enredadas. Os píxeis não se mantiveram confinados ao on-line, mas explodiram no mundo por meio de estilhaços de memes, spams, games e videoclipes, carregando todas as ameaças e temores que circulavam na web.

No filme, a imagem digital em circulação perturba as relações de causa e efeito, já que o "esparramar" dos píxeis corrompidos pelo vírus adquire caminhos inesperados. 0 resultado é uma espiral de perturbação. Assim como tantas produções que trazem a questão do uso da tecnologia por jovens, Videofilia esbarra em um tom moralista de punição. Imersos em álcool e drogas, os protagonistas se dão mal ao final. Como apontado pelo sufixo "filia", o título carrega uma mistura de êxtase e fobia em relação ao "vídeo", ou como queremos destacar, ao vídeo em circulação on-line. A afinidade patológica com a internet ganha ares tecnofóbicos, outra marca de diversas produções contemporâneas.

\section{APONTAMENTOS PARA REFLEXÃO - DESOBEDIÊNCIA E SUBVERSÃO POR MEIO DO PIXEL}

Sempre na iminência de sua manipulação e transformação, as imagens de Videofilia, contaminadas por um vírus, estão prestes a seguir por novas rotas. Como afirmou Rodowick, o presente imediato se orienta para um futuro já emergente (2007, p. 178), fazendo da visão uma atividade que antecipa menus de possíveis ações, como em nossa ininterrupta relação com as diversas telas que nos cercam. 0 que Videofilia parece fazer é embaralhar e esparramar os píxeis dessas telas, impossibilitando que as novas imagens formem um todo coeso. 0 rearranjo afeta o desenrolar dos eventos, gerando consequências extremas nas vidas dos personagens.

Neste artigo, buscamos realizar a análise fílmica de Videofilia sem enquadrar sua relação com a internet como tema, mas destacando as explorações narrativas e estéticas que se dão nesse encontro. Para tal, nos foi importante tanto a ideia de "retroalimentação" das mídias quanto o exercício de uma "retroalimentação" das teorias. Quer dizer, entrelaçamos a teoria que destaca o papel fundamental do legado do cinema na construção do fluxo audiovisual 24/7 (Casetti, Elsaesser, Rodowick) com as investigações contemporâneas sobre os traços artísticos e políticos das imagens na era da circulação on-line

$24 \mathrm{Ctrl+X}$ é uma variação do comando $\mathrm{Ctrl}+\mathrm{C}$, Ctrl+V (o famoso copiar e colar), criado em 1983 pelo cientista da computação estadunidense Larry Tesler, com grande impacto na edição de textos, sons e imagens. $C$ trl+X é o atalho para recortar o conteúdo selecionado para a área de transferência. 
(Steyerl). As contaminações e as idas e vindas entre esses pensamentos nos parecem imprescindíveis para abordar as reinvenções e novas poéticas do cinema pós-internet. Em Videofilia, destacamos as imagens pobres e a ostentação do pixel como um descompromisso com a nitidez, um estorvo proposital à corrente de "imagens limpas e ricas". Há uma postura de advertência, e até de denúncia, contra um padrão falsamente neutro difundido no fluxo das imagens digitais.

Se a realidade não é apenas refletida, mas produzida por imagens e telas, o pixel que as compõe também se prova cada vez mais relevante nos debates contemporâneos. No final de março de 2020, durante a pandemia do coronavírus, o filósofo francês Bruno Latour escreve o ensaio "Imaginar gestos que barrem o retorno da produção pré-crise"25. Ele convoca que nos coloquemos contra os modos de produção que não queremos que sejam retomados, defendendo que é importante erguer barreiras para evitar sua mera repetição. Para o autor, "não se trata de revolução, mas de dissolução, pixel por pixel" (Latour, 2020).

\section{REFERÊNCIAS}

Casetti, F. (2015). The Lumière galaxy: Seven key words for the cinema to come. Columbia University Press.

Castanheira, J. \& Felinto, E. (2019). Pós-cinemas: uma atualização sem começo e sem fim. Rebeca - Revista Brasileira de Estudos de Cinema e Audiovisual, 8(1), 12-16. http://dx.doi.org/10.22475/rebeca.v8n1.634

Charney, L. \& Schwartz, V. (Orgs.) (2010). 0 cinema e a invenção da vida moderna. Cosac Naify.

Crary, J. (2014). 24/7 Capitalismo tardio e os fins do sono (trad. J. Toledo). Cosac Naify.

Elsaesser, T. \& Hagener, M. (2015). Film theory: An introduction through the senses.

Elsaesser, T. (2018). Cinema como arqueologia das mídias (trad. C. Szlak). Edições Sesc São Paulo.

Gaudreault, A. \& Marion, P. (2016). 0 fim do cinema? Uma mídia em crise na era digital. Papirus.

Latour, B. (2020). Imaginar gestos que barrem o retorno da produção pré-crise. (trad. D. Danowski e E. Viveiros). AOC. https://n-1edicoes.org/008-1

Molero, J. (dir.) (2015). Videofilia: y otros síndromes virales [película]. Tiempo Libre.

25 Disponível em https://www.n-1edicoes.org/textos/28 
Regiane Akemi Ishii

Rodowick, D. (2007). The virtual life of film. Harvard University Press.

Steyerl, H. (2012). The wretched of the screen. Sternberg Press.

Steyerl, H. (2015). Em defesa da imagem ruim. Revista Serrote, (19), 186-199.

Steyerl, H. (2017). Duty free art - Art in the age of planetary civil war. Verso Books.

Xavier, I. (2010). Prefácio à edição brasileira. Em L. Charney e V. Schwartz (Orgs.), 0 cinema e a invenção da vida moderna. Cosac Naify. 